\title{
The Effect of Task-Based Language Teaching on Motivation and Grammatical Achievement of EFL Junior High School Students
}

\author{
Islam NamazianDost \\ Department of English Language Teaching, Ahvaz Branch, Islamic Azad University, Ahvaz, Iran \\ E-mail:e.namazi75@yahoo.com \\ Ghassem Bohloulzadeh \\ Department of Law, Central Tehran Branch, Islamic Azad University, Tehran, Iran \\ E-mail: ghassem_bohloulzadeh1971@yahoo.com \\ Abdolreza Pazhakh (Corresponding author) \\ Department of English, Dezful Branch, Islamic Azad University, Dezful, Iran \\ E-mail: pazhakh@gmail.com
}

Doi:10.7575/aiac.alls.v.8n.2p.243

URL: http://dx.doi.org/10.7575/aiac.alls.v.8n.2p.243
Received: $13 / 03 / 2017$

Accepted: 28/04/2017

\begin{abstract}
This research sought to investigate the effect of the effect of task-based language teaching on motivation and grammatical achievement of EFL junior high school students of Ahvaz. To fulfill the objectives of the study a Homogeneity test (Oxford Quick Placement Test) was administered among 100 students at the junior high school and finally 80 participants were selected. Then, they were divided into two subgroups, namely control and experimental groups. Before starting the treatment, a validated teacher-made grammar test in terms of the materials supposed to be covered in both groups was administered to them as the pre-test. Moreover, a motivation questionnaire were given to both groups at the beginning and at the end of study. Then the experimental group received the treatment, which was teaching and learning grammar through using task-based language teaching and the control group received traditional teaching which is teaching grammar through instruction on examples and drills proposed by the teacher. After 12 sessions of treatment, the two groups were administered the same teacher-made grammar test as posttest. Data were analyzed by Paired and Independent Samples t-test. The findings showed that the experimental group significantly performed better than the control group. Generally, the experimental groups outperformed the control groups. Furthermore, the results of motivation questionnaire show that there was a significant difference between the experimental and control groups' motivation in the post-test of questionnaire which implies that the experimental group's motivation increased significantly. The results suggest that task-based language teaching can be used in English classes to develop grammar ability among Iranian EFL learners.
\end{abstract}

Keywords: Strategy, Tasked-based Language Teaching (TBLT), Communicative language teaching (CLT), Motivation

\section{Introduction}

\subsection{Preliminaries}

Today, English language not only belongs to the American, British, Canadian, and Australian people, but it is also the language of the whole world. It knows no territories and boundaries and crosses all the borders and occupies them. On the other hand, many people logically think it is incumbent on them to learn English, because it is the language of the Internet and modernity, it has become much more than a school subject to its learners, and also it is a means to exchange experience and information through travel, email, phone and video-conferencing, so it is warmly welcomed by many nations (Cohen, 1990). We live in the era of information and communication and thus we need to share our new ideas and findings with the people all over the world. Being an internationally recognized language, most publications as well as website materials use English as their means of communication. In Iran, like in many other countries, there is a strong tendency toward learning/developing grammar ability in a foreign language, namely English (Brophy, 2010).

Therefore, in learning English for both foreign and second language, the learner should master the four essential skills including listening, speaking, reading and writing in order to comprehend and utilize the language accurately. These skills cannot stand alone; in other words, one skill will support the other skills (Afandi, Jufrizal, \& Narius, 2013). Thus, the learners cannot learn only one single skill. Moreover, in teaching and learning English, there are some sub skills included in the four skills such as vocabulary, pronunciation, and grammar. 
In the process of mastering the four noteworthy skills of English grammar is one of the essential perspectives to make right and significant sentences and articulations. Sentence structure is known as a base to shape and utilize a dialect. As indicated by Klammer, Muriel, and Angela (2000) "grammar is an arrangement of a language or a set of standards which in a perfect world identified with right sentences while utilizing the language" (p.3). It intends to create a good sentence; somebody ought to comprehend the grammar use of the language well. In accordance with this definition, Roberts (1953) states that grammar is a set of principles or particular guidelines to mastermind words and different components into a right sentence of the grammar. It gives meaning to any individual who utilizes the language either in speaking, listening, reading, and writing. In short, grammar is a set of rules and principles by which individuals can talk and write. They allow people to use their language easily and naturally most of the time. Thus, if someone wants to master a language, he or she ought to grasp and comprehend the tenets of the language well. To put it plainly, in order to comprehend and utilize English, one must have enough knowledge of grammar and the segments because it is closely related to its major skills which are utilized in daily communication because a language cannot be framed correctly without the information of its grammar (Afandi et al., 2013).

Now the question which is important to consider is: What is the suitable procedure for teaching and learning grammar for second and foreign language learners? In spite of all of the developments in the teaching of grammar in different EFL contexts, the traditional approach, i.e. "product approach" is still used in teaching grammar to learners in Iranian universities and colleges (Birjandi \& Malmir, 2011). Also, the quality of research on grammar in general and the research on the teaching of grammar in particular is very poor in Iran. Therefore, because of the poor status of EFL grammar in Iran due to the use of traditional, product-based approaches, the current study attempted to use Task-Based Language Teaching (TBLT) as a rather new and validated approach in the teaching of grammatical points.

Task-based language teaching (TBLT), which is a subcategory of communicative language teaching, is one of the most important methodologies in English teaching. In the past decades, TBLT has gained much attention from educators and researchers in various teaching fields. TBLT was developed in the 1980s under the influence of communicative language teaching and hence, the notion of "task" also derived from communicative approach (Branden, 2006). TBLT, also known as task-based language learning (TBLL) or task-based instruction (TBI) puts much emphasis on requiring learners to fulfill meaningful tasks and the use of authentic language by using the target language. According to Skehan (1998), for learners in TBLT, the first priority should be given to the accomplishment of learning tasks rather than the mastery of language forms. TBLT emphasizes that the language should be acquired naturally by accomplishing various tasks. It is believed that when students learn language through accomplishing a task they will be motivated. Therefore, motivation is critical for students when learning a second language. Maintaining suitable levels of motivation supports the process of language learning and makes it much more productive. Lightbown and Spada (1999) believed that motivation and a positive attitude have also been linked with second language acquisition.

Grammar, as one of the main language components, is of great importance for English learners. Newby (2003) believes that, "grammar is a subsystem in a network of other linguistic sub-systems and sub-skills" (p.105). From this interpretation, we can see a good command of grammar is crucial to the improvement of language learning. However, in Iranian English learning context, grammar is often a headache and a difficult process for many students. For many teachers, it is always a tough experience to figure out satisfactory ways for students to participate in classroom activities actively and effectively in grammar classes. The employment of effective teaching approaches in college writing classes is of great importance to students' learning outcomes. This study aims to provide a practical and helpful way to improve learners' grammar abilities by utilizing TBLT in classes.

\subsection{Statement of the Problem}

In recent years, there has been a growing interest in language teaching towards a Task-based approach to instruction (Ellis, 2003; Nunan, 2004; Prabhu, 1987; Skehan, 1996); Prabhu's approach still appeals to many researchers concerned with effective instructional activities. Ellis (2003) believes that Prabhu's classification of tasks is interesting because it rests on an account of the kind of cognitive operations that underlie the actual performance of different kinds of tasks. It is based on the premise that using language for reasoning fosters acquisition, a premise that is certainly intuitively appealing, but it is untested. There are few, if not any, empirical researches to date to show that TBLT activities work better for writing activities. The situation becomes more exacerbating when it comes to the context of Iran. Unfortunately, no study has incorporated the efficacy of task- types in learning grammar at the high school level in Iran. Thus it seems that a study concerning task types might be an actual attempt through which the influence of task type can be examined on grammar acquisition (Mohammadi, 2006).

Moreover, often, when faced with various problems, language teachers are in search of finding something that could create a difference in their classroom. The problems are generally caused by students' lack of motivation to the lesson. Increasing learners' motivation and performance has always been the primary concern of language teachers. A new approach, TBL, is applied to a traditional classroom situation with the aim of finding solutions to certain problems such as poor learner motivation (Nemat Tabrizi, 2011). Implementing a TBL approach in EFL classes creates variety for the students. Moreover, it enhances their learning, since TBL tasks encourage student involvement and lead to significant improvements regarding their language performance; and the students can find enough opportunities to express themselves in the target language (Khalili Sabet \& Tahriri, 2014).

Therefore, in order to enhance the grammar ability of Iranian junior high school EFL students, the researcher proposed using a procedure based on the use of tasks as the core unit of planning and instruction in language teaching called 
Task-Based language Teaching (TBLT). This study aimed to investigate the effects of using TBLT on developing the grammar of the EFL students in junior high school in Iran, and their motivation towards English.

\subsection{Objectives of the Study}

Iranian students have difficulty with learning English language and communication out of the class environment and doing some activities in English. As English is a foreign language and students do not have any exposure to it in real life situations. And the main reason for learning English as a second language acquisition is engaging in the environment enriched of language opportunities for the learners to learn and to achieve language. The teacher should design some activities and tasks similar to real contexts which foster students' motivation, interest, and raise conscious attention toward doing tasks and simultaneously academic achievement. The level of the learners is the main factor which the teacher should not ignore.

From another perspective, following the highlights of "TBLT" which argue students can learn from the Tasks that they are involved in (Tale \& Goodarzi, 2015), this study follows two objectives: it aims to investigate if task-based language teaching has any effect not only on EFL junior high school students' motivations but also on their grammatical achievements. That is, the researcher tries to check if there is any significant difference between Iranian junior EFL learners' knowledge of grammatical points in experimental and control group classes.

\subsection{Research Questions and Hypotheses}

This study aimed to answer the following questions:

1. Does task-based language teaching have any effect on EFL junior high school students' grammatical achievements?

2. Does task-based language teaching have any effect on EFL junior high school Students' motivations?

Regarding the mentioned questions, this study is based on the following null hypotheses:

H01. Task-based language teaching method has no significant effect on EFL junior high school students' motivations.

H02. Task-based language teaching method has no significant effect on EFL junior high school students' grammatical achievements.

\subsection{Significance of the Study}

The full development of children is fundamental to the education process. Training is geared to develop the cognitive, social, emotional, physical, spiritual and ethical dimensions of students. The findings of this study get a clear view on the significance of task-based language teaching in schools by gathering the available evidence and the influences this education will have on the professional development for use in pre-service courses and the in-service teacher education, curriculum and material developers, and policy makers for knowing about the principles of the main religions, customs, values, and beliefs of the main cultures. Providing activities in the school curriculum increases through communication and understanding each member's attitudes and perceptions. The comprehensive role of the teacher is demonstrated in his practical competency to facilitate learning by knowing about the principles and practices of the modern methods of teaching in addition to developing basic and transferable skills. Moreover, using different tasks in the students' classroom can create funny environment for students to learn, resulting improving their motivation.

This study is an attempt to investigate the effect of using task-based activities on grammar learning. In particular, its purpose is to find better and easier ways for teaching and learning grammar in foreign language and to make the students motivated and interested in language classrooms.

\section{Review of the Literature}

Learning strategies are the thoughts and actions we engage in, consciously or not, to learn new information. The goal of teaching learning strategies is to help students to consciously control how they learn so that they can be efficient, motivated, and independent language learners (Chamot, Barnhardt, El-Dinary, \& Robbins, 1999). Students who think and work strategically are more motivated to learn and have a higher sense of self-efficacy or confidence in their own learning ability. That is, strategic students perceive themselves as more able to succeed academically than students who do not know how to use strategies effectively. Students who expect to be successful at learning task generally are successful, and each successful learning experience increases motivation. Parallel to development in research in cognitive psychology, research on second and foreign language learning strategies has increased tremendously since the end of the 1960's. There exist several international second and foreign language (L2) learning strategies classifications (Ellis, 1990; O’Malley, Chamot, Stewner, Manzanares, Küpper, \& Russo, 1985; Oxford, 1990; Stern, 1992; Wenden \& Rubin, 1987.).

The most frequently referenced classifications of L2 learning strategies in foreign language literature are classifications by Naiman, Fröhlich, Stern, \& Todesco (1978), Rubin, \& Wenden (1987), Oxford (1990), O’Malley et al. (1985), Stern (1992) or Cohen \& Weaver (2006).

At least five basic classification types of language learning strategies can be identified: 1) classifications connected with research of good language learners (e.g., Rubin, 1975), 2) classifications based on psychological functions (e.g., O’Malley \& Chamot, 1990), 3) classifications with a linguistic background dealing with meaning mapping, language monitoring, formal and functional practice (e.g., Bialystok, 1981), or communication strategies such as paraphrasing and loanwords (e.g., Tarone, 1983), 4) classifications connected with language skills (e.g., Cohen, 1990; Cohen \& Weaver, 2006), 5) classifications based on the distinction of learning styles or types of learners. 
O'Malley and Chamot's (1990) definition of learning strategies and their key features is based on a cognitive theory of learning, particularly the cognitive information processing view of human thought and action. They define language learning strategies as the special thought and behaviors that individuals use to help their comprehension, learning, or retention of the new information. This definition is not, however, parallel to the definitions offered by Cohen (1998). Wenden (1987) defines language learning strategies in terms of three but related phenomena. First, these strategies refer to the learner's actual language learning behavior in the processes of learning and regulating the learning of the second language. Wenden's illustration of this definition implies that strategies are observable and rather conscious. Second, they refer to the learner's knowledge about strategies, i.e. their strategic knowledge. This knowledge is revealed when learners are asked to think of language learning other than their strategies, such as personal factors facilitating language learning, general principles for successful learning, the degree of the difficulty of learning a specific language, and their ability to use an L2. Wenden's assumption is that this knowledge is likely to influence a learner's choice of strategies. Unfortunately, Wenden does not take any further step to explain what strategies or strategy categories exemplify the three types of strategies she refers to.

Grammar is central to the teaching and learning of languages. It clarifies the sorts of words and word groups that make up sentences in any language and makes it possible for us to talk about language. In fact, grammar is the way in which sentences are organized and the language is designed, so while concentrating on right punctuation may be a touch exhausting, it truly is justified regardless of the time and exertion. If we don't know the rules of grammar, then we will never have the capacity to convey obviously and successfully in English language. People associate grammar with errors and accuracy. With the utilization of erroneous language structure sentences can get to be meaningless and their message is unclear (Soleimani \& Khandan, 2013). So, thinking about grammar helps us comprehend what makes sentences and sections clear and intriguing and exact. Grammar and language structure can be a piece of writing talks, when we and our students nearly read the sentences in verse and stories. Also, thinking about sentence structure means discovering that all dialects and all languages take after grammatical patterns.

Utilizing suitable grammar is considered as a prerequisite to be able to complete sentences in exchanging data and information. According to Swan (2005) grammar is the rules that show how words are joined, organized or changed to demonstrate certain sorts of meaning. Grammar is the way in which words change themselves and group together to make sentences. It is argued that a basic knowledge of grammar underlies the ability to utilize the language, to express meaning. The right spelling or words and sentence structure are utilized to increase errors. Moreover, grammar is a theory of language, of how language is set up together and how it functions. More particularly, "grammar is the study of wording. Wordings are characterized such that they are able to explain meaning" (Gerot \& Wignel, p. 1994). Ur (1991) defined Grammar as "the way language manipulates and combines words (or bits of words) in order to form longer units of meaning" (p.4). This definition is very close to the common understanding of grammar.

By learning grammar rules, learners can maintain a strategic distance from language fossilization and enhance their execution, among other related points of interest. In addition, knowing language structure principles make autonomous learners who can control their learning procedure when they are out of school and when time contains the learning knowledge to the classroom only.

Crystal (2004) states that grammar is the base of our capability to express ourselves. The more we know how it works, the more we can monitor the meaning and effectiveness of the way we and others use language. Furthermore, Maugham (1938) holds that it is vital to learn grammar, and it is ideal to compose grammatically than not, but it is well to recall that grammar is basic speech formulated.

To sum up, grammar refers composed sentence language structure. It includes the investigation of syntax (word order), clause and phrase structure, and the classification of parts of speech (e.g. noun, verb, predicate, clause, etc.). Grammar is not an immaterial arrangement of standards that can be neglected without results. It is the examination of principles which unite the words and go along with them to make right sentences (Weaver, McNally, \& Moerman, 2001). It has distinctive segments and the present study investigated preposition as the main component of grammar. It is explained more in the following section.

For many years, task based language teaching (TBLT) got a lot of attention of second language acquisition (SLA) researchers, teachers, curriculum developers, and teacher trainers (Branden, 2006). The SLA researchers and language instructors made a term, because of standard based SL classroom exercises (Long \& Norris, 2000). Long (1985) and Prabhu (1987) supported a system in which learners experience functional tasks that let them focus on significant undertakings and language use (Branden, 2006). In the TB guideline, the point is to make a prerequisite to learn and utilize. The errands will make their own language and produce a chance for learning language unequivocally. Willis and Willis (2007) have made an endeavor based structure. This undertaking based system making an association between the language errands and educational unit incorporates three segments and some sub-parts (Willis, \& Willis, 2007). According to this structure, educators don't unequivocally make the structures to be taught and the vocabulary to be secured in a unit, however they utilize tasks to accomplish a few finishes, as per the understudies' needs and supports. In addition, it may go past the customary technique for setting dialect direction presented by Skehan (1998) as the 3 Ps, Presentation, Practice and Production (Eliss, 2003). There are a few points of interest to this structure. This system moves past the idea of evaluation in a traditional perspective. TBLT structure can help instructors and understudies have open doors for correspondence. This methodology must be amalgamated with the three after components, language mindfulness, the intercultural skill, and the content-based methodology. 
One approach to language teaching that has received much attention over the last years is task-based approach. In taskbased instruction, the point of convergence of classroom exercises is on assignments, and furthermore on importance. Jane Willis' model of TBI (1996) is one of the best in which Learners begin by doing an open errand, without any emphasis on structure. In the wake of doing the undertaking and finished them, they expand how they did it. The upside of the task-based approach is that during the task the learners are allowed to put to utilize whatever language they wish, letting them to focus, totally, on the importance of their expressions. This makes a comparable genuine open circumstance (Richards and Rodgers, 2001). One of the disservices of TBLT is that the Learners get to be familiar; however their talks are not regularly articulated accurately. Notwithstanding, they use strategies to fulfill the tasks quickly and build up an alternate way in their language use and form.

With respect to the rising enthusiasm for inspiration in SLA, Ushioda (2009) expressed that: "Principally, SLA specialists have been occupied with inspiration since it appears to assume such a vital part in whether learners learn or not, the amount of exertion they put into realizing, to what extent they continue at learning, and how effectively they take in a language" (p. 218). Motivation is vital in instructing a youngster, subsequently educators and understudies ought to be spurred enough to instruct and to learn well. Kids are normally inquisitive and energetic to learn new things. As youngsters get to be more seasoned, their inspiration blurs. Right now folks and educators must discover approaches to keep students included in the learning process. Motivation is psychological matter that stirs a person to act towards a fancied end and removes, oversees, and keeps up certain end coordinated activities. It can be seen a driving power; "a mental one that strengths or strengthens a conduct toward a desired end" (Schacter, 2011, p.325). Motivation has roots in physiological, behavioral, subjective, and social zones (Schacter, 2011). To put it presently, motivation could be seen as the go for, or a mental reason of an activity (Today, 2013).

According to Dornyei (2005), L2 motivation research can be divided into three periods: (1) The social psychological period; (2) The cognitive- situated period; and (3) The process- oriented period of Gardner and his associates in Canada. The cognitive-situated period can be characterized by the research drawing on cognitive theories from educational psychology (Dornyei, 2005; as sited in Kang\& Kim, 2014, p.17).

Fotos and Ellis (1991) uncovered that the picking of "task-based language teaching" to impart about sentence structure is useful to both learning and correspondence. They likewise revealed that showing language structure informatively with TBI helped Japanese EFL understudies enhanced their comprehension of troublesome syntactic structures.

In a semi-experimental research with the title of the effect of Task-based method on learning of There is/ there are in English, Mohammadi (2006) investigated the effect of TBI on elementary students in Isfahan. Findings showed that TBI had a significant effect on students. The traditional approach does not have a significant effect on students' learning and did not guarantee the success of students.

Nemat Tabrizi (2011) attempted to provide new evidence for the efficacy of task-based techniques to speaking proficiency development of EFL learners. The primary focus of the study is to investigate the effects of task-based techniques on speaking proficiency development. In the second place, it tried to scrutinize the effect of gender on speaking proficiency development under task-based principles of language teaching. Accordingly, sixty male and female Iranian EFL participants from intermediate level were selected and assigned into two groups (experimental and control) on the basis of their performance on the interviews as pre-test. In continuation, each category was divided into two groups of males and females. At the end of the experimental period, the subjects in the two groups were interviewed as the post-test. A set of independent sample t-tests were conducted. It was found that the students of the experimental group, who experienced task-based principles of teaching speaking, performed remarkably better than those of the control group on the final speaking post-test. It was also concluded that gender was not a determining factor in speaking development under task-based approach.

Furthermore, Zhang and Hung (2012) have done a research for exploring the viability of the task-based instruction in big-sized class on Chinese college students' learning attainments, motivation and attitudes and their oral English performance. They have had two groups, the experimental group which received task-based instruction and the control group which received the same content with traditional methodology. At the final of the experiment, they found that the experimental group is likely to have presented significantly better learning attainment, oral English performance and while comparing with the control group. The experimental group tends to present more active and motivated learning than the control group based on data collected from individual interviews. And finally, it was concluded that task-based instruction in relation to participants of the English language has the potential of practicality and efficiency more than the traditional approach.

Hu (2013) conducted a study in order to identify in service language teachers' responses and perceptions about using task based teaching in their classrooms. Thirty public school English teachers were recruited in Beijing across school levels. Through participants' interviews and classroom observations, the researcher tried to find out how Chinese teachers of English at different levels of teaching respond to using task based teaching. Results revealed that teachers actively accepted using task based teaching in their classes. Furthermore, those who actively used task based teaching demonstrated different instructional foci in terms of task selection and task implementation.

One year later, Rezaeyan (2014) aimed to investigate the impact of task based language teaching on the academic achievement of Iranian EFL female learners in Yasuj high school. It is a quasi-experimental experiment. The sample of the study consisted of (48) female learners who were 14-15 years old at Alghadir high school in Yasuj, Iran. The selecting sample was convenience sampling method and divided into an experimental $(\mathrm{N}=24)$ and a control $(\mathrm{N}=24)$ 
group. The data were collected through two per and post -achievement test, both designed by Ministry of Education. The data obtained from the administration of the test were analyzed using descriptive analysis and independent samples t-tests and paired samples t-tests. Finding drawn from the analysis of data revealed that implementation of task-based teaching can significantly affect the learners' academic achievement in high school.

Pietri (2015) examined the effect of task-based learning with Thai students at Stamford International University (Hua Hin Campus, Thailand). The purpose of this study was to observe and test the impact of task-based learning on Thai students 'motivation in completing assignments related to English language learning. The results showed that task-based learning not only encourages students to learn and retain language skills, but also encourages their creativity. Furthermore, the degree of interactivity was considered an effective way to achieve substantial educational results by stimulating students 'motivation and willingness to learn and practice a foreign language.

\section{Method}

\subsection{Participants}

This research was conducted at Hazerat Masomeh junior High school in Ahvaz, Khouzestan, Iran. A sample of 80 out of 100 female students at the pre-intermediate level who took English as their course at school were selected based on an Oxford Quick Placement Test. They were all female students aged between 16 to 17 (forty five of them were 16 and thirty five were 17 years old). The students were all the same regarding their educational background, age and sex. None of them had ever lived in a foreign country or traveled to an English speaking country. To achieve the objectives of the present study and to evaluate the homogeneity level of the participants, all of them were given a homogeneity test who were considered as pre-intermediate students. Of course, their proficiency in English was the same (as they passed the English final exam in the previous year), but to get more sure about their proficiency, the researcher conducted an Oxford Quick Placement Test (Appendix A). It is worth noting that there were some very delicate individual differences among all of them (some of them were left handed); however, the researcher did her best to minimize all the contravening variables as much as possible and focus on the study. Two classes were selected and randomly divided into two groups, namely control and experimental groups. The experimental group received the treatment, which was teaching and learning grammar through task-based instruction. The control group just received placebo. The classes were conducted in the morning once a week; each session lasted about 90 minutes. Except for the conditions manipulated in favor of task-based instruction in the experimental group's classroom, the teacher, the source book, the allotted time for both groups and the method were the same.

\subsection{Instruments}

The following instruments were used in order to collect the data in this study.

\subsubsection{Oxford Quick Placement Test (OQPT)}

As it went on, the first instrument which was utilized in the present study to homogenize the participants was the Oxford Quick Placement Test (OQPT). It was utilized to measure the participants' language proficiency. As a Proficiency test, it is expected to be norm - referenced and is intended to "measure global language abilities" (Brown, 2005 , p. 2). One characteristic of a proficiency test, as a norm - referenced test, is that it should produce "scores which fall into a normal distribution" (p.5), which allows relative interpretations of the test scores in terms of "how each student's performance relates to the performances of all other students" (p. 4). The second characteristic of the test is that "the test must provide scores that form a wide distribution, so that interpretations of the differences among students will be as fair as possible" (p. 8). In other words, a proficiency test tends to test overall general language proficiency. As shown in Appendix (A), the test consists of sixty items with different question formats comprising of two parts (Part one and Part two). These different forms include such forms as multiple choice, item matching, and cloze test type items. In each item, there is a missing word for which there are four options. Students should find the correct item among these options. All of the 80 chosen participants for the present study were able to pass the test with a score between 28-37. The reason why the researcher of the study decided to utilize OQPT as the students' measure of proficiency was due to the fact that the test is a standard test of proficiency, and its validity and reliability were assumed to be satisfactory.

\subsubsection{Pre-test}

Before starting the research, the participants answered a teacher-made grammar test as a pretest (Appendix B). This test included two parts: one part was a true-false test which consisted of 22 items that the learners had to check the true and crossed out the false items and the other part was included 43 multiple choice items which required the learners to choose the correct choice. The reliability of tests was calculated through a pilot test and then the Cronbach Alpha formula value of 0.759 was obtained. To get sure about the Content Validity Index (CVI) of the test items, three teachers who also taught English for more than 10 years read through the tests and made some changes regarding the clarity, simplicity and the representativeness of items. Subsequently, the test was modified and then piloted on a similar group in another high school whose course book and level were the same. After applying validation and piloting, the necessary changes and modifications to achieve item characteristics, (i.e., item facility, item discrimination, and choice distribution) were made to the test and 5 items were considered inappropriate and omitted. Finally, 60 items were selected for the final version of the test. The allotted time was 80 minutes and the correct answer to each item received one point. There was no penalty for false responses. 


\subsubsection{Motivation Questionnaire}

An English learner questionnaire adopted from (You \& Dörnyei, in press) model of motivation was administered at the beginning as well as the end of the study (Appendix C). This questionnaire was first conducted by the School of English Studies of the University of Nottingham, UK, to better understand the thoughts and beliefs of learners of English. The questionnaire closed-ended items were accompanied by five response options for respondents to indicate the extent to which they agree or disagree with it by marking one of the responses ranging from "strongly agree" to "strongly disagree". This often used tool is called Likert scale which does not require the respondents to produce any free writing. The Questionnaire was developed to elicit relevant information on the participants' views of educational motivation. The questionnaire was given before instruction to find the level of their motivation. The modified questionnaire received the views of ten experts who were English teachers and familiar with the concept of second language learning and task-based language teaching. This step was vital to achieve a comprehensible and relevant questionnaire in terms of face and content validity (Kimberlin \& Winterstein, 2008). Moreover, a reliability of .793 was obtained after using Cronbach's Alpha test.

\subsubsection{Post-test}

The last instrument which was used in this study was a post test. At the end of the semester a post test was administered to the respondents of the study. The purpose of applying such a test was to find out the effectiveness of the treatment, i.e., using task-based language teaching on the students' grammar learning. That is, to obtain the results of the comparison between the experimental and control group in terms of learners' knowledge of grammar the teacher-made grammar test was used again. In fact, the same grammar test was used twice in this study, once as a pre-test and once as a posttest instrument. There was no difference between the pre-test and posttest in terms of time and the number of items. The only difference of posttest test from the pre-test was that the order of questions and alternatives was changed to wipe out the probable recall of pre-test answers.

This was important in order to find out whether the participants were able to choose the correct answer after the treatment was given to them. The post test was administered in the end of research which was after 12 sessions to test the learners' grammar learning. The pre- and post- tests were two tests prepared by the researcher. The validity of the test was also checked by those ten teachers who validated the pre-test and the reliability was computed through the application of a pilot test. Then the Cronbach Alpha formula and value of 0.881 was obtained.

\subsection{Data Collection Procedures}

At the beginning, two homogeneous classes from Hazerat Masomeh junior High school in Ahvaz, Khouzestan, were selected and given a Quick Placement Test to make them homogeneous. Then they were divided into two groups, namely, an experimental group and a control group. Next, both groups took a grammar test as a pretest which was developed by the researcher based on the course book content and was checked against validity and reliability measures. Nevertheless, the two groups were statistically compared via the results of the grammar pre-test. The pretest checked the participants' knowledge of grammar in both groups with respect to the grammatical points which were going to be presented in 12 sessions of the classroom. Then students were asked to fill out a questionnaire at the beginning and later at the end of the experiment to measure their motivation toward learning English. During the study the effect of task-based approach on the learners' motivation was investigated. The experimental group received the treatment which was using task-based language teaching based on the ongoing school program. The control group did not receive the research treatment; the participants in the control group just received placebo. At the end of the program to ensure the effectiveness of instructions and to assess learners' grammatical knowledge of the target language throughout the study, the grammar test was repeated at the end of the experiment, as posttest. The aim of this test was to check the grammar development of the participants and to determine the effectiveness of using task-based language teaching on grammar learning. When the data were all gathered via pretest-posttest and questionnaire, it was time to carry out the analysis.

\subsection{Data Analysis Procedures}

Since one of the objectives of the present study was to check the possible effect of task-based language teaching on motivation and grammar improvement of EFL Junior high school students, one part of the data was collected through a grammar test. Thus, the two different conditions of instruction were the independent variables of the study and the grammar test scores were the dependent variables. As the experimental and control groups were independent from each other, an Independent-Samples t-test was conducted for the analyses in order to compare the two groups' performance in answering the teacher made test. Before the treatment, all groups sat for a pretest. An Independent-Samples t-test was conducted to compare the means of the experimental group with that of control group. After that, when the treatment was implemented, the two groups sat for a posttest. The very same statistical procedure was applied here as well. An Independent-Samples t-test was conducted to compare the means of the experimental group with that of control group. Moreover, students' answers to the motivation questionnaire which was run prior and after the treatment were also analyzed and discussed. To sum up, after collecting data related to the performances of control and experimental groups, the researcher analyzed the data using SPSS (Statistical Package for Social Science) software. Independent and Paired-Samples t-tests were conducted to compare the means of experimental group with control group in pre-test, posttest and questionnaire to get the final results. The results are presented in details in the next section. 


\section{Results and Discussion}

\subsection{Analyzing the teacher-made grammar test as pre-test and post-test}

\subsubsection{Test of Normality}

In order to analyze the data obtained from the pretest-posttest administrations and the questionnaire, the SPSS (22) package was used. It is important to note that the researcher employed all the formulas with the level of significance set at 0.05. In data analysis, first of all the normality of distribution was investigated. This normality of the distribution, in fact, means that the sample is significantly representative of the population (Kaplan, 1964, p.236). In order to check this normality assumption, Kolmogorov-Smirnov (K-S) test was conducted. In this test, if the significance level is larger than .05 , then we can claim that the data are normally distributed and there is no significant difference between the sample and the population, hence our sample is representative of the population (Pallant, 2007). The results of Kolmogorov-Smirnov test are presented below.

Table 4.1 Test of normality

\begin{tabular}{|c|c|c|c|c|c|c|c|c|c|}
\hline \multirow{4}{*}{ 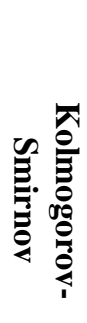 } & & \multicolumn{4}{|c|}{ Experimental } & \multicolumn{4}{|c|}{ Control } \\
\hline & & Pretest & Posttest & $\begin{array}{c}\mathrm{Q} \\
\text { Pretest }\end{array}$ & $\begin{array}{c}\mathrm{Q} \\
\text { Posttest }\end{array}$ & Pretest & $\begin{array}{c}\text { Posttes } \\
\mathrm{t}\end{array}$ & $\begin{array}{c}\mathrm{Q} \\
\text { Pretest }\end{array}$ & Q Posttest \\
\hline & $\begin{array}{l}\text { Stati } \\
\text { stic }\end{array}$ & .134 & .119 & .196 & .207 & .136 & .114 & .200 & .169 \\
\hline & Sig. & .068 & .164 & .000 & .000 & .059 & $.200^{*}$ & .000 & .006 \\
\hline
\end{tabular}

Note. Q = Questionnaire

Based on the information revealed in Table 4.1, the results of Kolmogorov-Smirnov test show that the distribution of the all the scores is normal ( $\mathrm{p}>0.05)$.

4.1.2 Descriptive Statistics

Table 4.2 presents descriptive information about pre-posttest and questionnaire scores of both experimental and control groups regarding their motivation and grammatical achievement.

Table 4.2 Descriptive Statistics

\begin{tabular}{|c|c|c|c|c|c|c|}
\hline & & $\mathrm{N}$ & Minimum & Maximum & Mean & Std. Deviation \\
\hline \multirow{4}{*}{ 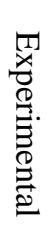 } & Pretest & 40 & 13.00 & 18.00 & 15.6000 & 1.46410 \\
\hline & Posttest & 40 & 30.00 & 38.00 & 33.8000 & 2.45158 \\
\hline & Q Pretest & 40 & 2.05 & 3.15 & 2.7808 & .24669 \\
\hline & Q Posttest & 40 & 4.28 & 5.53 & 4.7896 & .36677 \\
\hline \multirow{4}{*}{$\begin{array}{l}\stackrel{0}{ٍ} \\
0\end{array}$} & Pretest & 40 & 12.00 & 19.00 & 15.3000 & 1.68249 \\
\hline & Posttest & 40 & 25.00 & 32.00 & 28.6000 & 2.22803 \\
\hline & Q Pretest & 40 & 2.33 & 5.00 & 2.8138 & .41110 \\
\hline & Q Posttest & 40 & 2.60 & 5.53 & 4.4251 & .61206 \\
\hline
\end{tabular}

According to the statistics depicted in Table 4.2, in the 40 items of pretest of experimental group, the minimum score is 13 and the maximum score is 18 and their average is 15.60 , and in posttest the minimum is 30 and the maximum is 38 and their average is 33.80. Moreover, in the 40 items of pretest of control group, the minimum score is 12 and the maximum score is 19 and their average is 15.30 , and in posttest the minimum is 25 and the maximum is 32 and their average is 28.60. As illustrated in table 4.2, the results of descriptive statistics show that the scores of the students are close to each other and it seems that there is not remarkably significant difference between them.

\subsubsection{Inferential statistics}

Regarding the mean scores of two groups in pre-test there was no significant difference, but in order to be sure of close homogeneity of two groups, a t- test was run. As the mean of pretest scores in both experimental and control groups was checked out and the results indicated that the distribution of pretest mean scores in both groups was normal (Table 4.1), an Independent-Samples t-test was used (Table 4.3). The results of the test show that the mean of pretest scores in both experimental and control groups is the same. 
Table 4.3 Independent samples t-test results for participants' performance on pre-test

\begin{tabular}{ccccccc}
\hline & \multicolumn{2}{c}{$\begin{array}{c}\text { Levene's Test for } \\
\text { Equality of Variances }\end{array}$} & & \multicolumn{2}{c}{ t-test for Equality of Means } \\
\cline { 2 - 6 } & F & Sig. & t & df & $\begin{array}{c}\text { Sig. (2- } \\
\text { tailed) }\end{array}$ & Mean Difference \\
\hline Equal variances assumed & .547 & .462 & .851 & 78 & .398 & .30000 \\
\hline
\end{tabular}

According to Table 4.3, the significance level is higher than $0 / 05$, so the assumption of homogeneity of two variances will be accepted. This indicated that there was no significant difference between the mean scores of pretest in both experimental and control groups. Therefore, it can be concluded that both groups had similar performances and their proficiency level was almost the same. Figure 4.1 shows the results of Table 4.3 as graph. Similar Latin letters indicate no significant difference.

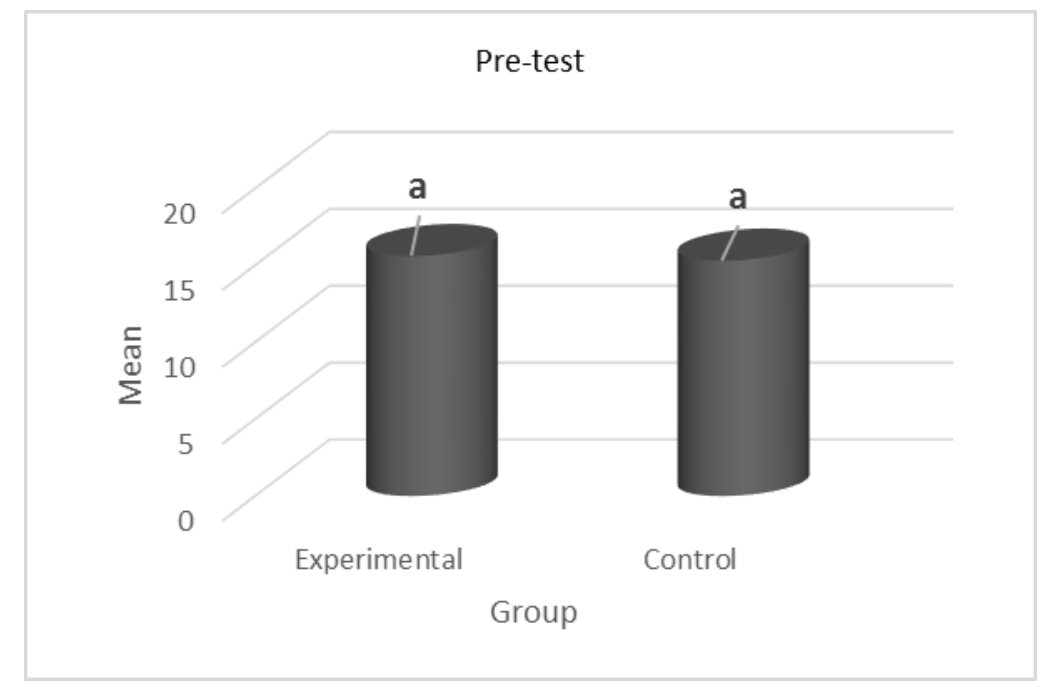

Figure 4.1 The mean of pre-test scores for experimental and control groups

Moreover, the result of independent t-test on posttest is presented in Table 4.4. In this test, the null hypothesis expresses the equality of the mean of posttest scores in both experimental and control groups and the opposite assumption shows the difference.

Table 4.4 Independent Samples t-test results for participants' performance on post-test

\begin{tabular}{|c|c|c|c|c|c|c|}
\hline & \multicolumn{3}{|c|}{$\begin{array}{c}\text { Levene's Test for } \\
\text { Equality of Variances }\end{array}$} & \multicolumn{3}{|c|}{ t-test for Equality of Means } \\
\hline & $\mathrm{F}$ & Sig. & $\mathrm{t}$ & df & $\begin{array}{l}\text { Sig. }(2- \\
\text { tailed) }\end{array}$ & $\begin{array}{c}\text { Mean } \\
\text { Difference }\end{array}$ \\
\hline Equal variances assumed & .652 & .422 & 9.928 & 78 & .000 & 5.20 \\
\hline
\end{tabular}

Comparing the performances of the two groups on posttest, the results of t-test suggest a $p$ value of .000 which is smaller than the significance level set for the study (0.05), hence a significance difference is suggested. As the posttest mean of experimental group was 5.20 scores higher than posttest mean of control group, it could be said that task-based language teaching in the experimental group positively affected the experimental group's knowledge. Figure 4.2 shows the results of Table 4.4 as graph. Different Latin letters indicate significant difference. 


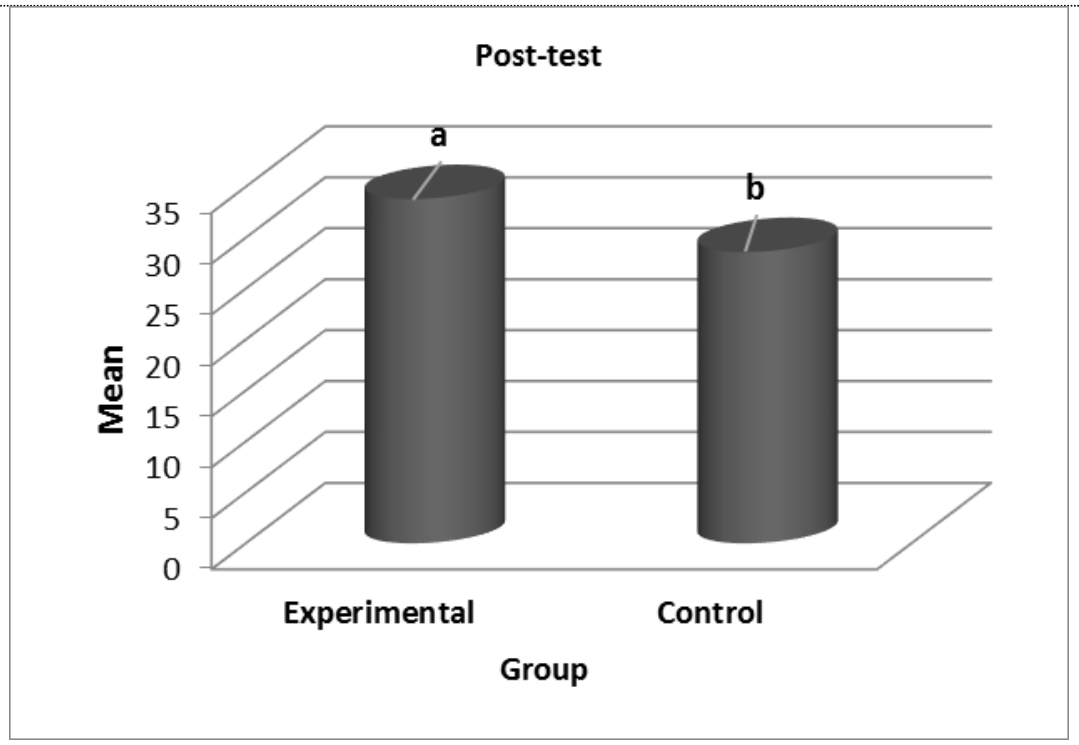

Figure 4.2 The mean of post-test scores for experimental and control groups

To further check the intra group changes, paired t-test was used. The mean analysis of pretest and post-test scores for the experimental group suggested a normal distribution so it was necessary to use Paired Samples t-test. The result of this test is presented in Table 4.5 .

Table 4.5 Paired samples t-test results comparing experimental group's performance on pretest and posttest

\begin{tabular}{ccccc} 
& Mean & $\mathrm{t}$ & $\mathrm{df}$ & Sig. (2-tailed) \\
\hline Posttest - Pretest & 18.20 & 39.91 & 39 & .000 \\
\hline
\end{tabular}

Table 4.4 shows that the amount of statistic $\mathrm{t}$ is $39.91(\mathrm{t}=39.91), \mathrm{df}=39(\mathrm{df}=39)$ and significance level is 0.000 which is less than 0.05 . This indicated that there was a significant difference between the mean of pre-test and post-test scores of experimental group. The mean of post-test is 18.20 points higher than the mean of pre-test. So, these results may imply that using task-based language teaching effectively affected grammatical knowledge of the experimental group. So instruction was effective in experimental group. Figure 4.3 shows the results of Table 4.5.

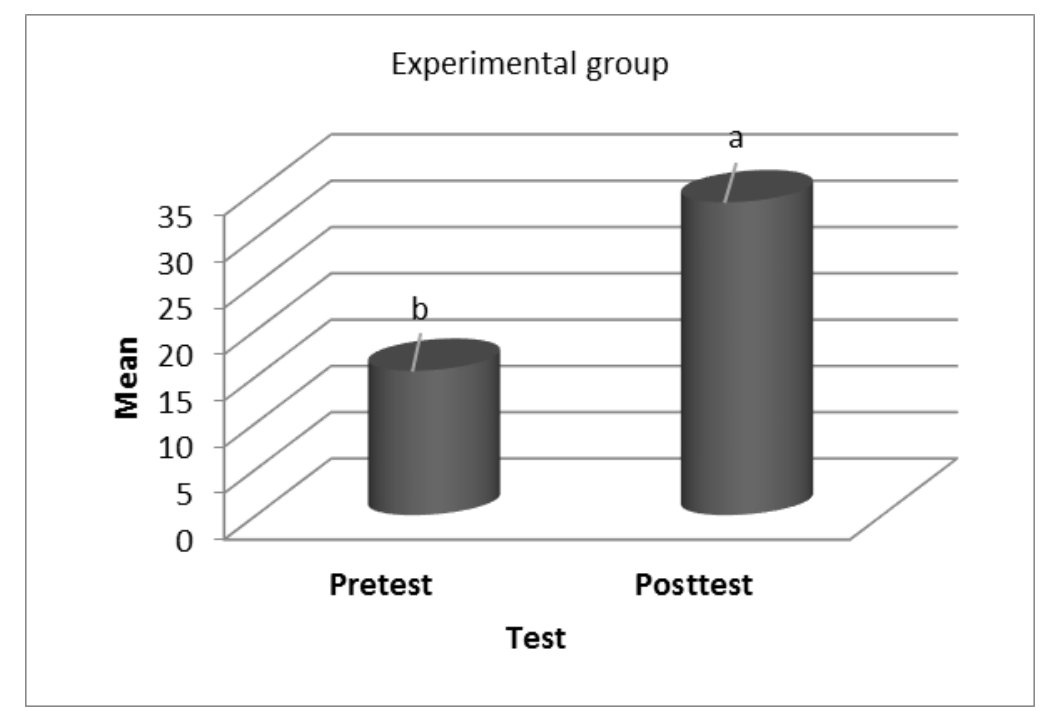

Figure 4.3. The mean scores of experimental group's performances on pretest and posttest

After comparing the experimental group' pre-posttest, the control groups performance on pre-test and post-test is also compared (Table 4.6).

Table 4.6 Paired Samples t-test results comparing control group's performances on pretest and posttest

\begin{tabular}{ccccc} 
& Mean & t & df & Sig. (2-tailed) \\
\hline Posttest - Pretest & 13.30 & 28.47 & 39 & .000 \\
\hline
\end{tabular}


Table 4.6 shows that the amount of statistic $t$ is 28.47 and the significance level is 0.000 which indicates that there was a significant difference between the mean of pre-test and post-test scores in control group. The mean of post-test scores is 13.3 points higher than the mean of pre-test scores. So, instruction was effective in the control group, too. Figure 4.4 shows the results of Table 4.6.

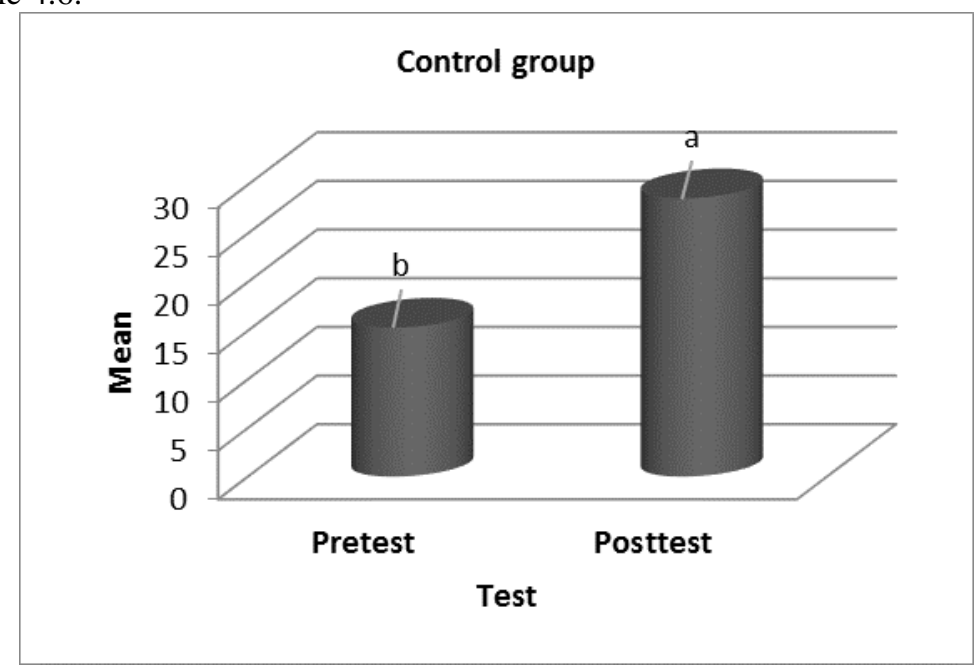

Figure 4.4 The mean scores of control group's performances on pretest and posttest

\subsection{Analyzing the Questionnaire of the study}

As presented in chapter three, the questionnaire was given to the participants twice, once as pre-test, i.e., before the treatment and then as posttest, i.e., after the treatment. Firstly, the students' motivation in both groups was investigate in the pre-test of questionnaire. The results are presented in Table (4.7).

Table 4.7 Mann-Whitney Test: Groups' ranks and test statistics relate to questionnaire scores in pre-test

\begin{tabular}{cccc}
\hline & $\mathrm{N}$ & Mean Rank & Sum of Ranks \\
\hline Experimental & 40 & 42.04 & 1681.50 \\
Control & 40 & 38.96 & 1558.50 \\
Total & 80 & & \\
Mann-Whitney U & & 738.500 & \\
Z & & -.596 & \\
Asymp. Sig. & & .551 & \\
\hline
\end{tabular}

As can be seen in table 4.8, the mean rank of participants in experimental and control group is 42.04 and 38.96 respectively. The significance level is 0.551 which means that the mean of questionnaire scores in experimental and control group is equal. This indicates that there was not any significant difference between the experimental and control groups' motivation in the pre-test of questionnaire. Figure 4.5 shows the results of Table 4.7 as graph. Similar Latin letters indicate no significant difference.

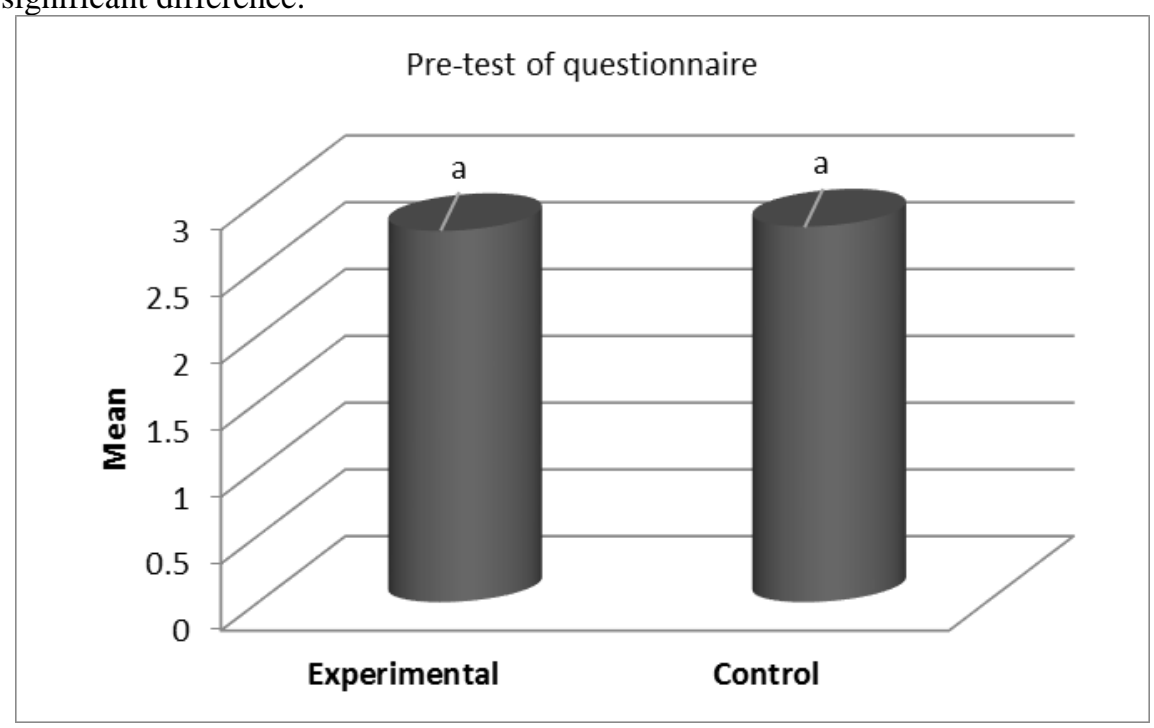

Figure 4.5 The mean scores of experimental and control groups in pre-test of questionnaire 
Secondly, the researcher compared the scores of both groups obtained in posttest of questionnaire using Mann-Whitney Test. The results of this test are presented in Table 4.8 .

Table 4.8 Table 4.7. Mann-Whitney Test: Groups' ranks and test statistics relate to questionnaire scores in post-test

\begin{tabular}{cccc}
\hline & N & Mean Rank & Sum of Ranks \\
\hline Experimental & 40 & 46.35 & 1854.00 \\
Control & 40 & 34.65 & \\
Total & 80 & & \\
Mann-Whitney U & & 566.000 & \\
Z & & -2.261 & \\
Asymp. Sig. & & .024 & \\
\hline
\end{tabular}

As can be seen in table 4.8, the mean rank of participants in experimental and control group is 46.35 and 34.65 respectively. The significance level is 0.024 which means that the mean of questionnaire scores in experimental and control group is not equal. According to the rank means, it is determined that mean rank of questionnaire scores in experimental group is more than the mean rank of questionnaire scores in control group. This indicates that there was a significant difference between the experimental and control groups' motivation in the post-test of questionnaire which implies that experimental group's motivation increased. Figure 4.6 shows the results of Table 4.8 as graph. Different Latin letters indicate significant difference.

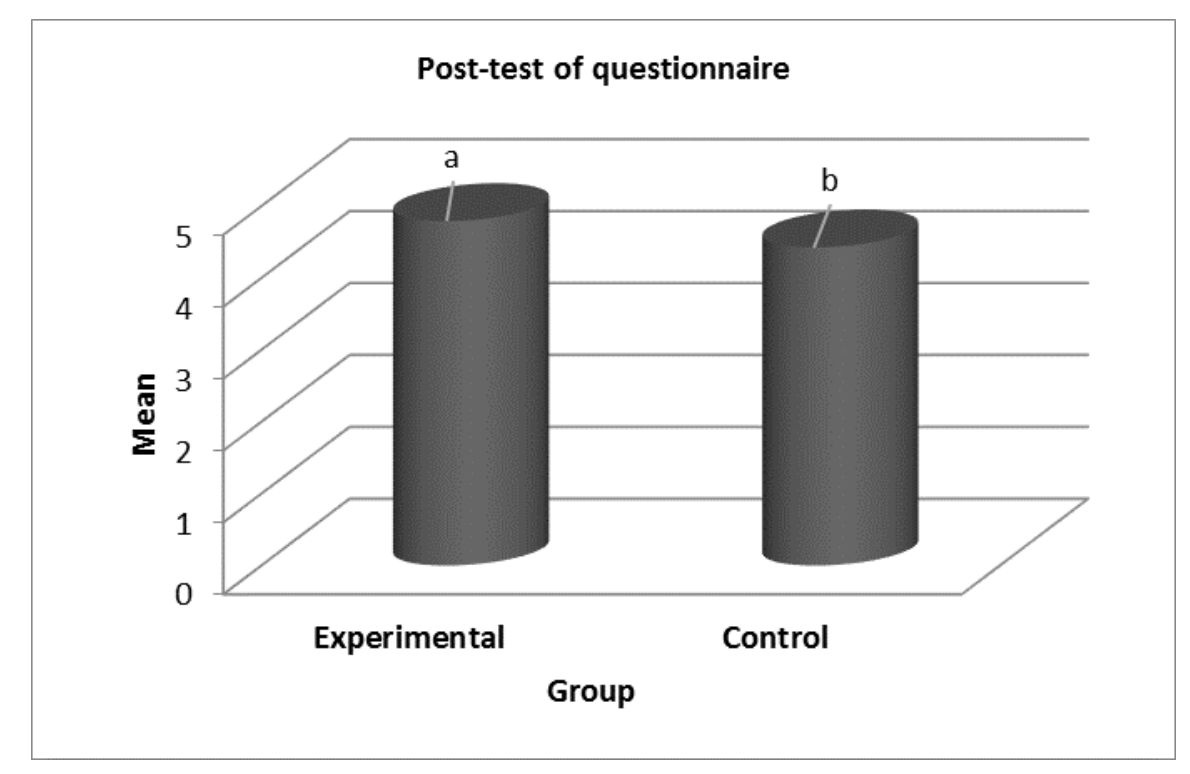

Figure 4.6 The mean scores of experimental and control groups in post-test of questionnaire

To further check the intra group changes related to motivation the following analyses was conducted. In order to find out about the experimental group motivation's progress after the treatment, it was decided that the participants' motivation's scores in pre-test of questionnaire would be compared to the post-test ones.

Table 4.9 Wilcoxon Signed Ranks Test: Experimental group' ranks and test statistics related to pre-test and post-test scores of questionnaire

\begin{tabular}{cccc}
\hline Pretest - Posttest of $\mathrm{Q}^{*}$. & $\mathrm{N}$ & Mean Rank & Sum of Ranks \\
\hline Negative Ranks & $0^{\mathrm{a}}$ & .00 & .00 \\
Positive Ranks & $40^{\mathrm{b}}$ & 20.50 & 820.00 \\
Ties & $0^{\mathrm{c}}$ & & \\
Total & 40 & & \\
\hline
\end{tabular}




\begin{tabular}{cccc}
\hline Pretest - Posttest of Q*. & $\mathrm{N}$ & Mean Rank & Sum of Ranks \\
\hline Negative Ranks & $0^{\mathrm{a}}$ & .00 & .00 \\
Positive Ranks & $40^{\mathrm{b}}$ & 20.50 & 820.00 \\
Ties & $0^{\mathrm{c}}$ & & \\
$\mathrm{Z}$ & & -5.512 & \\
Asymp. Sig. & & .000 & \\
\hline
\end{tabular}

Note. * $\mathrm{Q}=$ questionnaire
a. posttest $1<$ pretest 1
b. posttest $1>$ pretest 1
c. posttest $1=$ pretest 1

As table 4.9 shows, the p-value is 0.000 which is smaller than 0.05 , indicating that there is a significant difference between the mean of questionnaire scores of pretest and those of posttest in experimental group. As the scores of all 40 learners in pre-test questionnaire is less than posttest, so the mean of questionnaire scores in experimental group's posttest is higher than pre-test, and experimental group' motivation significantly increased. It can be concluded that the taskbased language teaching was effective. Figure 4.7 shows the results of Table 4.9 as graph. Different Latin letters indicate significant difference.

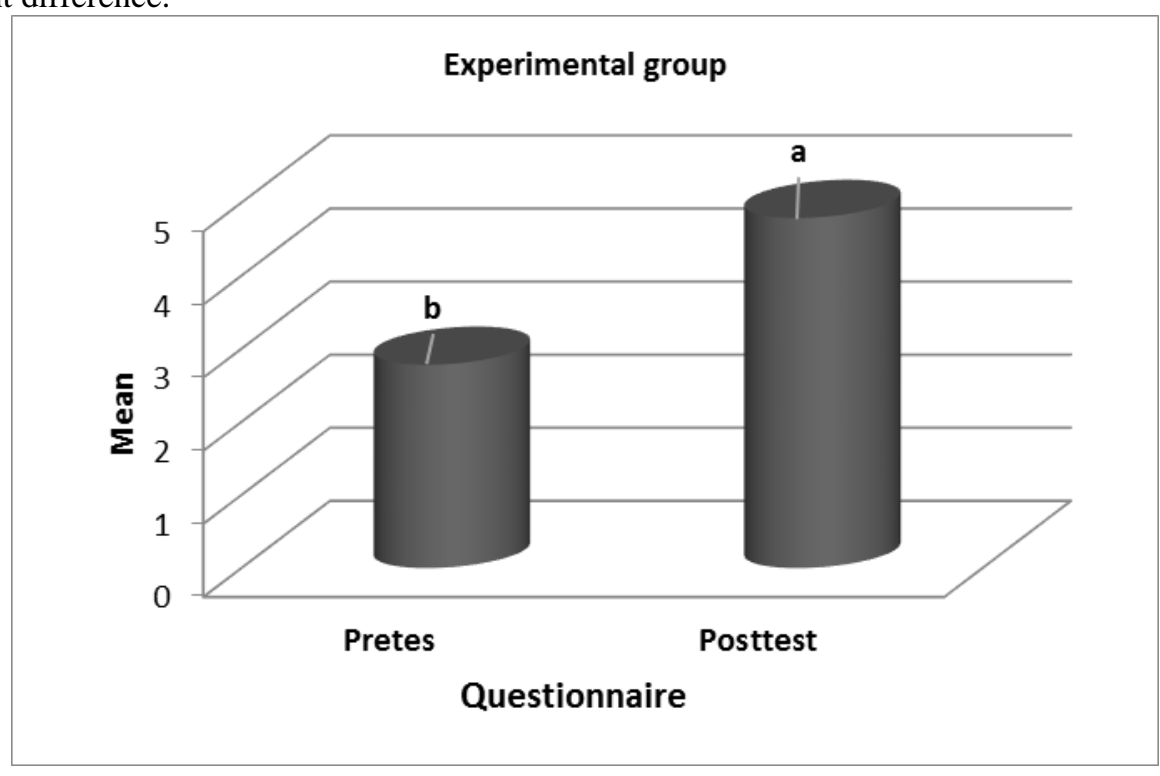

Figure 4.7 The mean scores of experimental group in pre-test and post-test of questionnaire

Finally, the control group's performance in the pre-posttest of questionnaire was investigated and analyzed using a Wilcoxon Signed Ranks Test. The results of this test provided in Table 4.10.

Table 4.10 Wilcoxon Signed Ranks Test: Control group' ranks and test statistics related to pre-test and post-test scores of questionnaire

\begin{tabular}{cccc}
\hline Pretest - Posttest of Q* & N & Mean Rank & Sum of Ranks \\
\hline Negative Ranks & $0^{\mathrm{a}}$ & .00 & .00 \\
Positive Ranks & $37^{\mathrm{b}}$ & 19.00 & 703.00 \\
Ties & $3^{\mathrm{c}}$ & & \\
Total & 40 & -5.305 & \\
\hline Z & & .000 & \\
Asymp. Sig. & &
\end{tabular}

Note. * $\mathrm{Q}=$ questionnaire
a. posttest $1<$ pretest 1
b. posttest $1>$ pretest 1
c. posttest $1=$ pretest 1 
As table 4.10 shows, the motivation score of 37 participants in pre-test is less than their post-test ones and the score of 3 participants did not change. Moreover, based on table 4.9, the significance level is 0.000 which is smaller than 0.05 , it means that there is a significant difference between the mean of questionnaire scores in pretest and posttest of control group. As the score of 37 participants in pre-test is less than post-test, it shows that the mean rank of motivation scores in post-test of control group is higher than their pre-test, concluding that motivation in control group was also significantly increased. Figure 4.8 shows the results of Table 4.10 as graph.

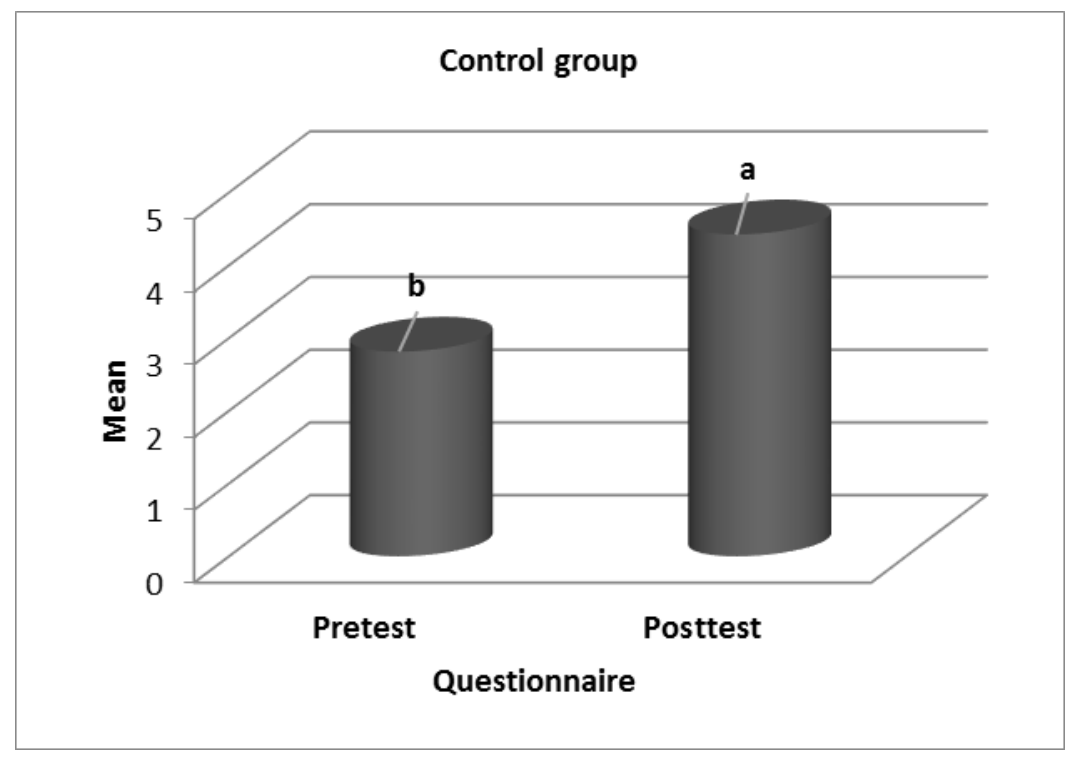

Figure 4.8 The mean scores of control group in pre-test and post-test of questionnaire

\subsection{Discussion}

Discussion of the findings focuses on answering the research questions to accept or reject the null hypotheses. Two research questions and their answers are as follow:

RQ1. Does task-based language teaching have any effect on EFL junior high school students' grammatical achievements?

In order to answer the first research question, the researcher compared the two groups of participants in the pre and post-tests. The pre-test was compared to the post-test to show any difference between the participants' performance on developing grammatical knowledge concerned with using task-based language teaching. After analyzing the data, the results showed that there was not a significant difference among students ' performance in pre-test, but in contrast there was a significant difference among the performances of the two groups in the post-test. Since the experimental groups outperformed the control groups, teaching through using TBLT is supposed to improve the grammar ability of junior high school students. It could be also observed that experimental group who received grammatical points via using taskbased language teaching got better scores and their performance was better than the control group. It is worth mentioning that whereas all two experimental and control groups increased their scores from pretest to posttest; the teaching through using TBLT was more effective than teaching directly by the teacher himself. The outcomes additionally show that TBLT is a useful way of acquiring grammar and learning language components. In the present study, some tasks were used. It indicates that the participants who were learned through tasks performed better than those who did not.

Regarding the use of TBLT which is a suitable technique for language learning, the results of this study support Nemat Tabrizi (2011) who found the positive effects of task-based techniques on speaking proficiency development of EFL learners. Also the findings of Zhang and Hung (2012) that concluded using task-based instruction in big-sized class in China for college students' learning attainments, motivation and attitudes and their oral English performance leads to learning development are consistent with the findings of this research which both confirm the positive effect of TBLT on grammar development.

The results of this study are also congruent to the study of Rezaeyan (2014); he investigated the impact of task based language teaching on the academic achievement of Iranian EFL female learners in Yasuj high school. Finding drawn from the analysis of data revealed that implementation of task-based teaching can significantly affect the learners' academic achievement in high school.

RQ2. Does task-based language teaching have any effect on EFL junior high school Students' motivations?

In order to arrive at a logical answer to the second research question, the obtained data were analyzed through independent and paired samples t-tests. According to results presented in chapter 4, there was a significant difference in among experimental group's motivation using TBLT and control group which received grammar instruction directly and conventionally by the teacher. Based on obtained results the means of two groups were different. 
In addition, the results gained from descriptive and inferential statistics of two groups in the pre and post-tests of motivation questionnaire indicated an increase in the mean score of experimental group in the post-test in contrast to the control group. Through the administration of a Mann-Whitney Test and the comparison between the two groups in the post-test, $P$ value was 0.024 which was greater than 0.05 . This indicates that there was a significant difference between the experimental and control groups' motivation in the post-test of questionnaire which implies that experimental group's motivation significantly increased.

These results also supported the study conducted by Pietri (2015) in which confirmed the effect of task-based learning with Thai students at Stamford International University (Hua Hin Campus, Thailand). The purpose of this study was to observe and test the impact of task-based learning on Thai students 'motivation in completing assignments related to English language learning. The results showed that task-based learning not only encourages students to learn and retain language skills, but also encourages their creativity. Furthermore, the degree of interactivity was considered an effective way to achieve substantial educational results by stimulating students' motivation and willingness to learn and practice a foreign language.

\section{Conclusion}

The research into the effectiveness of task-based language teaching on students' grammatical knowledge and motivation was shown to have produced extremely positive results. The activities and tasks designed by the researcher attempted to assess the students in real-world situations, in which they may find themselves needing to use English in everyday situations. This study, although limited in scope, was an attempt to investigate the impact of TBI on promoting the grammatical proficiency of Iranian junior high school EFL learners, as well as to gauge the motivation of EFL leaners after implementing TBLT. The survey indicated the significant influence of TBLT on the grammatical proficiency of junior high school EFL learners. The findings provided evidence that the learners who performed tasks became better motivated than those who didn`t which means that TBLT had a positive and significant effect on the motivation of EFL learners who experienced grammar learning through this method of instruction.

As this study began with the assumption that using TBLT could enhance the Iranian pre-intermediate EFL learners' grammar learning ability, the experimental group was received the grammatical points through using TBLT in the classroom. And the control group received conventional instruction such as drills, explanation by the teacher himself. The instructor explored to see if the application using different kinds of tasks has any effect on the Iranian EFL learners' grammar improvement and their motivation. Having administered the pre-test, post-test and questionnaire and analyzing the data through specific statistical analysis of Independent and paired samples t-tests, the researchers found that results indicated that the instruction of using TBLT did affect the learners' grammar learning and improvement as well as their motivation.

From all these perspectives and viewpoints, it is plain to see though a few students are not in favor of TBLT, most students give positive affirmations and admit that TBLT indeed enhances their learning motivation and helps them a lot in their study, not only in grammar, but also many other aspects such as reading, writing and speaking.

Based on the research findings, this study can provide the following implications and suggest some ideas to EFL learners and teachers. Interested researchers in the domains of grammar learning strategies may also put implications presented in this study into thoughtful account. On the basis of findings, it is suggested that some time must be devoted in grammar classes to use different types of task-based activities. In fact, enough opportunity should be given to the participants to follow the pre-task, task cycle, and language focus stages of task-based approach in the classroom. Similarly, certain kinds of task-based activities may be helpful to students in order to make them motivated and interested enough to facilitate negotiation and increase the level of their general language proficiency, as some researches have pointed out (e.g., Pica, 1994). Hopefully, this study may draw the material designers' attention to include special task-based activities sections in grammar materials. By providing more opportunity for doing different kinds of task-based activities in the books, there may be more acceleration in the process of grammar and also in motivating students to be involved in the interactions to be more accurate learner. Moreover, much information can be found by getting learners to do language tasks. Information of the study provides valuable data about the students' grammar learning and how to develop it. The results may be of relevance to task designers and teachers in better understanding the TBLT. The type and amount of TBLT in this study may give teachers a measure when deciding how much time to dedicate to structures. Studies such as these are likely to make teachers to feel comfortable applying TBLT in language classes. Replication of the study to other populations is called for before accepting above conclusions with confidence.

Furthermore, in TBLT, students have harmonious relationships with their group members and often do their utmost to finish and present their tasks to the whole class as well as provide prompt help to others. This kind of communication enhances their overall abilities. According to Vygotsky (1978), social interaction plays a crucial role in the development of one's cognition. TBLT not only develops learners' linguistic skills but also nonlinguistic qualities through constant interactions and communications with each other.

In the course of this research many questions have risen some of which are included here with the hope that they will be pursued and investigated.

1. It is strongly suggested that a research with the same characteristics of this study including more participants be conducted to provide more generalization in case similar findings are obtained. 
2. Similar studies can be done on other proficiency levels, namely elementary, intermediate, upper intermediate and advanced, to check age and proficiency levels as other variables.

3. This study did not include male students. Due to gender performance, future research on grammar learning would need to focus on the EFL learners for male students. Is there a significant comparison between female and male EFL learners?

4. A future study is essential in which the immediate and delayed post-tests are conducted at different time intervals to show the effectiveness of using TBLT in shorter and longer periods.

5. Other skills such as listening comprehension, speaking or reading skills are recommended to be investigated in future.

\section{References}

Afandi, W., Jufrizal, J., \& Narius, D. (2013). The ability of the third grade students in using different kinds of prepositios. Journal of English Language Teaching, 1(25), 625-639.

Bialystok, E. (1981). The role of conscious strategies in second language proficiency'. Modern Language Journal, 65(4), 24-35.

Birjandi P., \& Malmir, A. (2011). The effect of task-based approach on the Iranian advanced EFL learners' narrative vs. Expository writing. Iranian Journal of Applied Language Studies, 2(5), 1-26

Branden, K. V. (2006). Task Based Language Education from theory to practice. Cambridge: Cambridge university press.

Brophy, J. (2010). Motivating students to learn. New York: Routledge.

Chamot, A. U., Barnhardt, S., El-Dinary, P. B., \& Robbins, J. (1999). The learning strategies handbook. White Plains, NY: Addison Wesley Longman.

Cohen, A. (1990). Language Learning: insights for learners, teachers, and researchers. New York, Newbury House.

Cohen, A. (1998). Strategies in Learning and Using a Second Language. New York, Addison Wesley Longman Inc.

Cohen, A. D., \& Weaver, S. J. (2006). Styles- and strategies-based instruction. A teachers' guide. Minneapolis: Centre for Advanced research on language Acquisition, University of Minnesota.

Crystal, D. (2004). Rediscover grammar (3rd ed.). Harlow, Essex: Pearson Education.

Dörnyei, Z. (2005). The psychology of the language learner: Individual differences in second language acquisition. Mahwah, NJ: Lawrence Erlbaum.

Ellis, R. (1990). Understanding second language acquisition. Oxford: Oxford University Press.

Eliss, R. (2003). Task-based language learning and teaching. Oxford: Oxford University Press.

Fotos, S. and Ellis, R. (1991). Communicating about grammar: A task based approach. TESOL Quarterly, 25, 605-628.

Gerot, L., \& Wignell, P. (1994). Making sense of functional grammar. Sydney: Tanya Stabler.

Hu, R. (2013). Task-based language teaching: responses from Chinese teachers of English. The Electronic Journal for English as a Second Language, 16(4), 1-24.

Kapalan, A. (1964). The conduct of inquiry: methodology for behavioral science. San Francisco: Chandler Publishing Co.

Khalili Sabet, M., \& Tahriri, A. (2014). The impact of task-based approach on Iranian EFL learners" motivation in writing research abstracts. Journal of Language Teaching and Research, 5(4), 953-962.

Klammer, T. P., Muriel, R. S., \& Angela, D. V. (2000). Analyzing English grammar. San Fransisco: Pearson Education Company.

Lightbown, P. M., \& Spada, N. (1999). How languages are learned. Oxford, OUP.

Long, M. (1985). A role for instruction in second language acquisition: Task-based. In K. Hyltenstam, \& M. Pienemann, Modelling and assessing, 377-93.

Long, M.H. \& Norris, J. M. (2000). Task-based teaching and assessment. In M. Byram (ed.) encyclopedia of language teaching, p.597-603.. London: Routledge

Maugham, S. W. (1938). The summing up. England: Garden City Publishing Company.

Mohammadi. M. (2006). The effect of task-based method on learning of there is/ there are in English. M.A Thesis. Isfahan, Isfahan University. (Persian).

Naiman, N., Frohlich, M., Stern, H. and Todesco, A. (1978). The good language learner'. Research in Education Series, No. 7, Toronto, Ontario Institute for Studies in Education.

Nemat Tabrizi, A. R. (2011). The effect of using task-based activities on speaking proficiency of EFL learners, The Third Asian Conference on Education 2011 Official Osaka, Japan Proceeding. 334-345. 
Newby, D. (2003). Cognitive communicative theory of pedagogical grammar. Habilitationsschrift: Karl-Francens Universität Graz.

Nunan, D. (2004). Task-Based Language Teaching. Cambridge: Cambridge University Press.

O‘Malley, J. \& Chamot, A. (1990). Learning Strategies in Second Language Acquisition. Cambridge, Cambridge University Press.

O’Malley, J. M., Chamot, A. U., Stewner-Manzanares, G., Küpper, L., \& Russo, R. P. (1985). Learning strategies used by beginning and intermediate ESl students. Language Learning, 35(1), 21-4.

Oxford, r. 1. (1990). Language learning strategies: what every teacher should know. Boston: Heinle \& Heinle.

Pallant, J. (2007). SPSS, survival manual, a step by step guide to data analysis using SPSS for Windows. New York, NY, Open University Press.

Pietri, N. J. M. (2015). The Effects of Task-Based Learning on Thai Students' Skills and Motivation. Asean journal of management \& innovation, 3(4), 72-80.

Prabhu, N. (1 987). Second language pedagogy. Oxford: Oxford University Press.

Rezaeyan, M. (2014). On the impact of task-based teaching on academic achievement of Iranian EFL learners (case study: female high school students in Yasuj). International Journal of Language Learning and Applied Linguistics World (IJLLALW), 7 (3), 476-493.

Richard, J. C., \& Rodgers, T. (2001). Approaches and methods in language teaching. Cambridge: Cambridge University Press.

Roberts, P. (1953). Understanding grammar. New York: Harper and Row Publishers.

Rubin, J. 1975. What the good language learner can teach us'. TESOL Quarterly, 9, $41-51$.

Schacter, D. (2011). Psychology. United States of America: Catherine Woods.

Skehan, P. (1996). A framework for the implementation of task- based instruction. Applied Linguistics, 17 (1), 38-62.

Soleimani, H., \& Khandan, M. (2013). The effect of telling short stories on learning grammar among EFL high school students in Iran. International Journal of Language Learning and Applied Linguistics World, 4(2), 110-122.

Stern, H. H. (1992). Issues and options in language teaching. Oxford: Oxford University Press.

Swan, M. (2005). What is grammar? In Beaven, B (ed.), IATEFL. Cardiff Conference Selections: 60-61.

Tale, M., \& Goodarzi, A. (2015). The impacts of task-based teaching on grammar learning by Iranian first grade high school students. International Journal of Applied Linguistics \& English Literature, 4(4), 145-153.

Tarone, E. (1980). Communication strategies, foreigner talk, and repair in interlanguage‘. Language Learning, 30 (2): 417-431.

Today, P. (2013). Motivation. Retrieved from psychology today: http://www.psychologytoday.com/

Ur, P. (1991). Grammar practice activities. A practical guide for teachers. Cambridge: Cambridge University Press.

Ushioda, E. (2009). A person-in-context relational view of emergent motivation, self and identity. In Z. Dornyei \& E. Ushioda (Eds.), Motivation, language identity and the L2 self (pp. 215-228). Bristol: Multilingual Matters.

Vygotsky, L. S. (1978). Mind in society: The development of higher psychological processes. (M. Cole, V. JohnSteiner, S. Scribner, \& E. Souberman, Eds.). Cambridge, MA: Harvard University Press.

Weaver, C., McNally, C., \& Moerman, S. (2001). To grammar or not to grammar: That is not the question! Voices from the Middle, 8(3). 17-33. Retrieved from

http://www.learner.org/workshops/middlewriting/images/pdf/W8ReadGrama.pdf.

Wenden, A. L. (1987). Incorporating learner training in the classroom. In A. Wenden \& Joan Rubin (eds), 159-167.

Wenden, A., \& Rubin, J. (1987). Learner strategies in language learning. New Jersey: Prentice Hall.

Willis, J. (1 996). A framework for task-based learning. Harlow: Longman Addison.

Willis, D., \& Willis, J. (2007). Doing task-based teaching. Oxford: Oxford University press.

Zhang, X., \& Hung, S-C. (2012). A case study of exploring viability of task-based instruction on college English teaching in big-sized class. Journal of Language Teaching and Research, 4(4), 693-699. 